International Journal of Multidisciplinary Research AND ANALysis

ISSN(print): 2643-9840, ISSN(online): 2643-9875

Volume 04 Issue 10 October 2021

DOI: 10.47191/ijmra/v4-i10-09, Impact Factor: 6.072

Page No.- $1406-1410$

\title{
Clinical and Neurological Symptoms in Acute Brain Stroke from Gender Dymorphism and Age Features
}

\author{
N.M. Vakhabova1, G.S. Rakhimbaeva², M.M. Asadullaev ${ }^{3}$, SH.A. Jangirov ${ }^{4}$ \\ 1,2,3,4 Tashkent Medical Academy.
}

ABSTRACT: To date, CVD, in particular acute cerebrovascular accidents, have a clear tendency to increase. The existing domestic and especially foreign literature testifies to the established important medical and social problems of acute cerebral stroke in the society of humanity around the world. Stroke can develop at any age, but its frequency and prevalence increase with age. About $80 \%$ of strokes occur in people over 65 , with age having a major impact on stroke outcomes.

KEYWORDS: Stroke, elderly patients, thrombosis.

\section{INTRODUCTION}

The increase in the likelihood of developing a stroke in the elderly is due to age-related changes, primarily, of both the blood vessels supplying the brain and the brain itself. It is known that risk factors for the development of stroke and especially the pathophysiological mechanisms of ischemic brain damage differ in elderly and young people. Moreover, elderly patients are characterized by more severe neurological symptoms with the formation of poorly or not recoverable paralysis, higher cortical functions (motor and sensory aphasia, apraxia, gnosis, acalculia, agraphia and alexia ...), a sensitive and coordinating sphere and a relatively severe course stroke. Also, elderly patients often receive less effective therapy than younger patients, and cerebral stroke develops mainly against the background of myxpatology (cerebral atherosclerosis, arterial hypertension. their combination, diabetic micro- and macroangiopathies, hemodynamically significant and sometimes insignificant stenoses, pathological deformities of the vessels of the brachiocephalic system ...), which, of course, causes an unfavorable outcome of the disease. The patient's age is one of the main non-modifiable risk factors, regardless of the type, as well as the subtype of stroke. After age 55, the likelihood of having a stroke doubles every ten years, regardless of gender [WolfeC., 2009]. It has been shown that $75-89 \%$ of stroke cases develop after 65 years, $50 \%$ of them - in patients over 70 years and about $25 \%$ - after 85 years, while age negatively affects the outcomes of stroke [Sundseth A., Faiz K. W., Ronning O. M., 2014]. Moreover, all of the above clinical issues of stroke development have their own characteristics in men and women.

The purpose of the study was to study comparative indicators of clinical and neurological studies of acute cerebral strokes in men and women in different age groups.

This work analyzes the results of a complex (clinical and neurological, instrumental and neuroimaging research methods) clinical examination of 225 patients who received treatment in the intensive care and neurological departments of 1 TMA clinic. The selection criteria were: patients with ischemic stroke in the acute period aged 44 to 90 years and above. The average age of men is $65.3 \pm 7.63$ years, of women $-76.3 \pm 6.17$ years.

The age gradation of the examined patients of the main group was divided into 3 groups: mean age 44-59, elderly age 60-74 and senile 75-90 years. Patients were systematized in accordance with the classification of cerebral vascular lesions by E.V. Schmidt (1975) in a modified version.

Moreover, the social conditions of all the subjects were satisfactory.

In the main group, pensioners met in $95.4 \%$, of whom 53 persons (30.6\%) had cardiovascular disability. There were only 8 workers among the patients of the main group (4.6\%; 8/173). Interestingly, 66 patients ( 24 men and 42 women) had a recurrent stroke (38.7\%).

Exclusion criteria were oncological and hematological diseases, severe renal and hepatic insufficiency. 


\section{Clinical and Neurological Symptoms in Acute Brain Stroke from Gender Dymorphism and Age Features}

\section{THE MAIN FINDINGS AND RESULTS}

An in-depth analysis of 181 observations of different types of IS in persons aged 42-60 years (53 observations), elderly (73 patients aged 60-74 years) and senile (54 patients aged 75-90 years). The patients were divided into 3 groups depending on their age.

Among people aged 42-60 years, a 2-fold predominance of men with IS (66.2\%) was found compared with the elderly (31.5\%). The regularity of the prevalence of women with age has been established, so if at the age of 42-60 years, their percentage with IS was $33.7 \%$, then at the age of $75-90$ years - $68.5 \%$.

Other authors cite similar data [6]. This, apparently, is explained by the predominance of risk factors in the form of smoking (35.8\%), alcoholism, combined factors in men aged $42-60$ years $(p<0.05)$ and an increase in the number of elderly women in the social structure of the population. smoothing of gender differences due to an increase in combined risk factors in elderly and senile women $(p<0.05)$. The risk of developing IS in older women may be associated with a drop in estrogen levels since menopause.

Among people aged $42-60$ years, atherothrombotic stroke (ATI) was $49.5 \%$, cardioembolic stroke (CEI) - $16.8 \%$, lacunar stroke (LCI) - 20.0\%, hemodynamic stroke (HDI) - $13.7 \%$. In all age groups, ATI prevailed, in the elderly, LCI was the second in frequency, CEI and GDI were the third, and in elderly people, $\mathrm{LCI}$ gave way to $\mathrm{CEI}$, which indicates an increase in cardiac pathology with age.

Among men aged $42-60$ and 60-74, a significant $(P<0.05)$ prevalence of ATI $(p<0.05)$ was revealed, which amounted to $65.6 \%$ and $66.7 \%$, respectively, compared with $21.9 \%$ and $31.1 \%$ of observations of ATI in women.

In elderly people, a decrease in the proportion of HDI, LCl was noted due to an increase in the percentage of patients with ATI to $67.7 \%$ and $60.0 \%$, respectively, among men and women. CEI was encountered equally often in men and women in all age groups, which makes it possible to level the gender factor of its appearance.

Taking into account the heterogeneity of stroke in persons aged $42-60$ years, the highest percentage $(p<0.05)$ of the factor of smoking $(66.3 \%)$, dyslipidemia $(62.1 \%)$, psychoemotional stress $(45.3 \%)(p<0.05)$. In elderly and senile patients, the smoking factor significantly decreases $(\mathrm{P}<0.05)$.

In elderly patients, hypodynamia, overweight, dyslipidemia prevailed $(p<0.05)$ in the absence of clear gender differences. The data of other authors indicate that in the presence of three out of five risk factors, the likelihood of developing a stroke increases 8 times [6], and a combination of more than three risk factors is significantly more common in elderly patients (57.4\%), compared with patients of the age $44-59$ years old (37.9\%).

Patients aged 44-59 years in the structure of background diseases revealed a predominance of arterial hypertension (90.5\%), the presence of atherosclerosis (87.4\%), heart rhythm disturbances and rheumatism (45.3 and $47.4 \%$, respectively), diabetes mellitus (23.2\%). Transient ischemic attacks (TIA) and ischemic heart disease (CHD) in persons aged 44-59 years were found in $18.9 \%$ of cases. There was a significant predominance of atherosclerosis, arterial hypertension, coronary artery disease, TIA, rheumatism in men $(p<0.05)$, and diabetes mellitus and heart rhythm disturbances in women $(p<0.05)$.

With age, the percentage of arterial hypertension increased due to an increase in the proportion of atherosclerosis $(p$ $<0.05$ ), the proportion of coronary artery disease, TIA and heart rhythm disturbances increased. There was a leveling of gender differences in the structure of background diseases due to an increase in the proportion of atherosclerosis in women $(p<0.05)$, and diabetes mellitus in elderly men $(p<0.05)$. At the same time, in elderly male patients, the prevalence of the proportion of coronary artery disease and TIA in the structure of background diseases remained $(p<0.05)$.

The average age in the comparison group was $59.8 \pm 0.67$ years. Men accounted for $40.4 \%$ and women $59.6 \%$.

Comparative analysis of this group of surveyed showed the predominance of the nosology of DCE in the middle age group (51.9\%), and in the elderly group it is comparatively less (42.3\%) than the average age, but significantly different from that of senile age $(5.8 \%)$.

Consequently, DCE is formed mainly in middle and old age, and in senile age it is more expressed by the development of complications in the form of acute stroke. When studying these indicators in the sexual aspect, in middle age it was observed in men in $42.9 \%$ and in women in $81.8 \%$. in the elderly, in men, in $47.6 \%$, in women, in $54.5 \%$, and finally in the senile in men, in $9.5 \%$, and in women, in $4.5 \%$.

According to observations, at admission in patients of the main group in the acute stage of ischemic stroke, the following prevailed: general cerebral disorders $80.9 \%$ (140 patients) against the background of focal neurological clinical symptoms, depending on the localization of the ischemic process and the basin of the damaged cerebral vessel. hemiparesis and hemiplegia were observed in $65.3 \%$; speech disorders in $59.5 \%$ of cases (103 patients). Cerebellar symptoms were also recorded 


\section{Clinical and Neurological Symptoms in Acute Brain Stroke from Gender Dymorphism and Age Features}

in the form of an intention with a finger test, ataxia with a calcaneal knee test (in 81.5\%, 141 patients); Depending on age, we also established distinctive features in terms of the frequency of occurrence of neurological disorders (Table 3 ).

As can be seen from the presented data, in middle-aged patients, the course of IS is noted to be milder than in elderly and senile patients. So pyramidal insufficiency in the form of hemiparesis and hemiplegia in middle age was registered in $33.9 \%$ of cases, in the elderly in $78.5 \%$, and in senile in $95.2 \%$, i.e. with increasing age, there was a statistically significant increase in the severity of focal neurological symptoms, indicating the severity of stroke, accompanied by gross motor disorders. The same tendency was observed in the frequency of the formation of disorders of the higher cortical functions in the form of motor and sensory aphasia. If in middle age speech disorders were detected in $42.4 \%$ of cases, in the elderly - in $64.5 \%$, then in senile - in $85.7 \%$ of the examined.

Thus, neurological symptoms of ischemic stroke in elderly and senile people, as a rule, were dissociated, with cerebral symptoms prevailing (80.8\%). In $20 \%$ of cases, general cerebral symptoms were due to somatic diseases.

A statistical study of the representation of focal neurological symptoms showed that central paresis of the facial nerve was observed in $140(80.9 \%)$, central paresis of the hypoglossal nerve in $130(75.1 \%)$, anisoreflexia in $122(70.5 \%)$, decreased convergence and weakness. accommodation in 125 (72.3\%), oral automatism reflexes in 151 (87.3\%), positive Romberg symptom in 145 (83.8\%), intention in PNP in 117 (67.6\%), and finally ataxia in CAT in 63 (36.41\%)). The existing clinical neurological symptoms indicate brain damage due to circulatory disorders and at the same time, the doctor shows the localization of the ischemic focus and, accordingly, the cerebral vessel basin.) When analyzing the above neurological symptoms, the study of them in three age groups is of greatest interest. As can be seen from the data presented, there is a dependence of the increase in the incidence of central paresis of the VII and XII pairs of FMN with age, so in middle age the percentage of this symptom was $64.4 \%$, and in senile $-95.2 \%$, in old age this symptom was noted $88,2 \%$, i.e. 1.1 times less often in contrast to senile and 1.4 times more often depending on middle age Involvement of the hypoglossal nerve in the pathological process in the form of central paresis was observed in middle age in $57.6 \%$ of cases, in the elderly in $83.9 \%$, and $85.7 \%$ in senile. A similar picture was observed with the frequency of occurrence of tendon and periosteal anisoreflexia. in old age, this symptom was noted in $88.2 \%$, i.e. 1.1 times less often in contrast to senile and 1.4 times more often depending on middle age Involvement of the hypoglossal nerve in the pathological process in the form of central paresis was observed in middle age in $57.6 \%$ of cases, in the elderly in $83.9 \%$, and $85.7 \%$ in senile. A similar picture was observed with the frequency of occurrence of tendon and periosteal anisoreflexia. in old age, this symptom was noted in $88.2 \%$, i.e. 1.1 times less often in contrast to senile and 1.4 times more often depending on middle age Involvement of the hypoglossal nerve in the pathological process in the form of central paresis was observed in middle age in $57.6 \%$ of cases, in the elderly in $83.9 \%$, and $85.7 \%$ in senile. A similar picture was observed with the frequency of occurrence of tendon and periosteal anisoreflexia.

Decreased convergence, poor accommodation was found in 31 (52.5\%) patient at the age of 44-59 years, in 75 patients at the age of 60-74 years and in 19 patients in old age (75-90 years). Reflexes of oral automatism were observed, respectively in $48(81.4 \%)$, in $83(89.2 \%)$ and in $20(95.2 \%)$ patients, according to their age. Instability in the Romberg position was also diagnosed with a progressive nature with increasing age $(79.7 \%, 83.9 \%$ and $95.2 \%$, respectively).

Intention during the finger-nose test was found in more than half of the examined patients with IS, and had comparatively high numbers in old age. With the knee-heel test, a statistically dependent frequency of occurrence was noted, so at the age of $44-59$ years $-15.3 \%, 60-74$ years $-41.9 \%$, and at $75-90$ years $-71.4 \%$.

\section{CONCLUSIONS}

As can be seen from the obtained factual material, the frequency and severity of focal neurological symptoms have a direct correlation with age. The older the age, the developing neurological and clinical symptoms are more rough and difficult to form and in frequency clearly predominates in elderly and senile people. At the same time, the resuscitator and neurologist are given the opportunity to establish a topical diagnosis, i.e. localization of the damaged medulla due to ischemia. Often, the results of a complete and thorough examination of the neurological status are more accurate than other paraclinical and instrumental studies, up to neuroimaging (MSCT and MRI). Of course, if the neurological status is correctly interpreted and analyzed, taking into account the severity of one or another focal neurological symptomatology and also the age characteristics identified by us, then it will be easier for the attending physician to determine the appropriate drugs for full and rational therapy. In addition to the above, neurological deficit, when grouped into clinical syndromes, will make it possible to find out a specific pool of cerebral vessels (middle, anterior, vertebral or basilar). 


\section{REFERENCES}

1) Г.С. Рахимбаева, Г.С., Ю.А. Мусаева, Ю.А., Рахимбердиев, Ш.Р.(2017). Пути прогнозирования ишемического инсульта и транзиторной ишемической атаки с использованием международных шкал. Журнал теоретической и клинической медицины,номер 3,130-133.

2) Рахимбаева, Г.С. (2021).Постковидныйцеребро-астенический синдром. Журнал неврологии и нейрохирургических исследований 2(2).

3) Вахабова, Н.М. (2021). Структура клинико-неврологических симптомов при острых мозговых инсультах у мужчин и женщин в пожилом и старческом возрасте. Журнал неврологии и нейрохирургических исследований 2(3).

4) Асадуллаев, М.М., Рахимбаева, Г.С., Вахабова, Н.М., Жангиров, Ш. (2021). Ўткир ишемик инсульт ривожланишдаги патогенетик механизмлар. Збірник наукових прац SCIENTIA

5) Асадуллаев, М.М., Рахимбаева, Г.С., Вахабова, Н.М., Жангиров, Ш. (2021). Частота основных неврологических симптомов при ишемическом инсульте среди больных пожилого возраста.Збірник наукових прац SCIENTIA

6) Tolibova, N., Vakhabova, N., Shirasava, U. (2017). Gender differences in stroke subtypes, severity, risk factors, and outcomes amont elderly patients with acute ischemic stroke among Uzbek population. CEREBROVASCULAR DISEASES 43

7) Tolibova, N., \&Vakhabova, N. (2017). Gender differences in stroke subtypes, severity, risk factors, and outcomes among elderly patients with acute ischemic stroke in Uzbekistan. Journal of the Neurological Sciences, 381, 377.

8) Asadullaev, M. M., Saidvaliev, F. S., Shermukhamedova, F. K., ZhK, R., \&Vakhabova, N. M. (2012). Assessment of multimodal effect of cytoflavin in the acute brain stroke in patients with metabolic syndrome. Zhurnalnevrologiiipsikhiatriiimeni SS Korsakova, 112(10), 24-27.

9) Makhmudovich, A. M., Sattarovna, R. G., Maksudovna, V. N., \&Maksudovich, A. K. (2020). The Application Of Preparation Mavix In The Complex Treatment Of Ischemic Stroke In The Elderly Age. The American Journal of Medical Sciences and Pharmaceutical Research, 2(12), 55-63.

10) Maksud, A., Nargiza, V., \&Hamidjon, A. (2020). Risk Factors and Background Diseases in Different Variants of Ischemic Stroke in the Elderly and Senile Age. International Journal on Orange Technologies, 2(10), 86-88.

11) Ergasheva, M., \&Vakhabova, N. (2019). New gender-influenced stroke study: Cognitive manifestations in acute ischemic stroke in Uzbekistan. Journal of the Neurological Sciences, 405, 115.

12) Ergasheva, M., Vakhabova, N., \&Rakhimbaeva, G. (2019). Gender, aging and background diseases influence on the new neuronosological structure of acute ischemic stroke in Uzbekistan. Journal of the Neurological Sciences, 405, 115.

13) Вахабова, Н. М., Азизова, Р. Б., \&Абдуллаева, Н. Н. (2019). Гендерные особенности факторов риска и фоновых заболеваний при разных вариантах ишемического инсульта у лиц пожилого и старческого возраста.

14) Akramova, D., Rakhimbaeva, G., Vakhabova, N., \&Narzikulova, M. (2017, January). The frequency of ischemic stroke depending on the season and it's gender features. In CEREBROVASCULAR DISEASES (Vol. 43). ALLSCHWILERSTRASSE 10, CH-4009 BASEL, SWITZERLAND: KARGER.

15) Umarov, A., \&Vakhabova, N. (2017, January). Hormonal status in patients with ischemic stroke in uzbekistan-cortisol, estradiol and testosteron. In CEREBROVASCULAR DISEASES (Vol. 43). ALLSCHWILERSTRASSE 10, CH-4009 BASEL, SWITZERLAND: KARGER.

16) Maksudovna, V. N. (2016). Indirect influence of hormonal status on the development of ischemic insult and its gender peculiarities. European science review, (9-10).

17) Umarov, A., Vakhabova, N., Prokhorova, A., \&Narzikulova, M. (2016). PS-82 GENDER FEATURES OF THE RENINANGIOTENSIN-ALDOSTERONE SYSTEM (RAAS) IN PATIENTS WITH ARTERIAL HYPERTENSION IN UZBEKISTAN. Journal of Hypertension, 34, e497.

18) Umarov, A., Prokhorova, A., Rakhimbaeva, G., \&Vakhabova, N. (2016, January). Stroke indidence and association with risk factors in women in Uzbekistan. In CEREBROVASCULAR DISEASES (Vol. 41, pp. 212-212). ALLSCHWILERSTRASSE 10, CH-4009 BASEL, SWITZERLAND: KARGER.

19) Асадуллаев, М. М., Саидвалиев, Ф. С., Шермухамедова, Ф. К., Ризвонов, Ж. К., \& Вахабова, Н. М. (2012). Оценка мультимодального действия цитофлавина при остром мозговом инсульте, развившемся на фоне метаболического синдрома. Журнал неврологии и психиатрии им. СС Корсакова, 112(10), 24-27.

20) Makhmudovich, A. M., Sattarovna, R. G., Maksudovna, V. N., \&Azamatovich, J. S. (2021). HyperhomocysteinemiaAndPathogenetic Mechanisms Of Ischemic Stroke. The American Journal of Medical Sciences and Pharmaceutical Research, 3(02), 66-76. 


\section{Clinical and Neurological Symptoms in Acute Brain Stroke from Gender Dymorphism and Age Features}

21) Makhmudova, U., \&Vakhabova, N. (2019). Gender dependent neuropsychological manifestations study in patients with acute ischemic stroke in Uzbekistan. Journal of the Neurological Sciences, 405, 118-119.

22) Makhmudova, U., Rakhimbaeva, G., \&Vakhabova, N. (2019). New approach of risk factors and background diseases role in acute ischemic stroke in elderly and senile-aged patients in Uzbekistan. Journal of the Neurological Sciences, 405, 118

23) Tolibova, N., \&Vakhabova, N. (2017). Stroke incidence and association with risk factors in women in Uzbekistan. Journal of the Neurological Sciences, 381, 377.

24) Tolibova, N., \&Vakhabova, N. (2017). Gender differences in stroke subtypes, severity, risk factors, and outcomes among elderly patients with acute ischemic stroke in Uzbekistan. Journal of the Neurological Sciences, $381,377$.

25) Umarov, A., \&Vakhabova, N. (2017, January). Hormonal status in patients with acute ischemic stroke in uzbekistancortisol and insulin-like growth factor-1 igf. In CEREBROVASCULAR DISEASES (Vol. 43). ALLSCHWILERSTRASSE 10, CH4009 BASEL, SWITZERLAND: KARGER.

26) Tolibova, N., \&Vakhabova,N. (2017, January). Homocysteine levels and functional outcome in patients with ischemic stroke in Uzbekistan. In CEREBROVASCULAR DISEASES (Vol. 43). ALLSCHWILERSTRASSE 10, CH-4009 BASEL, SWITZERLAND: KARGER.

27) Akramova, D., Rakhimbaeva, G., Vakhabova, N., \&Akramova., N. (2017). Stroke incidence and association with risk factorsin women in Uzbekistan. CEREBROVASCULAR DISEASES (Vol. 43)

28) .Asadullaev, M.M., Rakhimbaeva, G.S., Vakhabova, N.M., Asadullaev, H.M., MirzaakhmedovFarruhMiradilovich, M., Saidnosirov .,O.Q. //Gender Features of Neurological Manifestations in Ischemic Stroke-International Journal Of Pharmaceutical Research.

29) Umarov, Azamatjon., Vakhobova, Nargiza., Asadullaev Maksud.,(2021). Gender characteristics of the main arteries of the head. WCN 2021.

30) Umarov, Azamatjon., Vakhobova, Nargiza., Rakhimbaeva, Golnora., Asadullaev, Maksud.,(2021). The Gender features and season related ischemic stroke and its frequency. WCN 2021 